Dialectologia 16 (2016), 117-141.

ISSN: 2013-2247

Received 19 April 2014.

Accepted 28 August 2014.

\title{
BIDIRECTIONAL LINGUISTIC CHANGE IN RURAL CHILD AND ADOLESCENT LANGUAGE IN SYRIA
}

\author{
Rania HABIB \\ Syracuse University \\ rhabib@syr.edu
}

\begin{abstract}
Investigating the spread of the urban feature the glottal stop [?] in place of the rural voiceless uvular stop [q] in the speech of rural children and adolescents in the Syrian village, Oyoun Al-Wadi, a bidirectional linguistic change is observed. Girls retain their mothers' urban feature in preadolescence and adolescence; boys who initially acquire the urban feature start switching to the rural feature around age eight and increase their use of this feature with age. Thus, the observed variation and changes are genderand age-related and result from different meanings associated with urban and rural sounds. Preadolescence emerges as the period in which kids are emotionally involved in building a social identity, indicating early development of sociolinguistic competence.
\end{abstract}

\section{Keywords}

rural vs. urban, Syrian Arabic, variation and change, children and adolescents, gender

\section{CAMBIO LINGÜÍSTICO BIDIRECCIONAL EN EL HABLA RURAL DE NIÑOS Y ADOLESCENTES EN SIRIA}

\section{Resumen}

Investigando sobre la propagación de la oclusiva glotal [?] urbana en lugar oclusiva uvular [q] rural en el habla rural de niños y adolescentes en la localidad siria de Oyoun Al-Wadi se observa un cambio lingüístico bidireccional. Las jóvenes conservan la realización urbana de sus madres en la preadolescencia y en la adolescencia; los jóvenes, que adquieren inicialmente la realización urbana empiezan a cambiar a la realización rural cuando tienen alrededor de ocho años e incrementan su uso con la edad. Así, la variación observada y cambios están relacionados con el género y la edad y son el resultado de diferentes significados asociados con formas urbanas y rurales. La preadolescencia es el período en el que los niños

${ }^{*}$ College of Arts and Sciences. Languages, Literatures, and Linguistics. 325 HB Crouse Hall. NY. USA. 
están involucrados emocionalmente en la construcción de una identidad social, lo que muestra el desarrollo temprano de la competencia sociolingüística.

\section{Palabras clave}

rural vs. urbano, sirio árabe, variación y cambio, niños y adolescentes, género

\section{Introduction}

This study investigates the spread of the urban feature the glottal stop [?] (in Arabic hamza) in place of the rural voiceless uvular stop [q] (in Arabic qaf) in the vernacular Arabic of non-migrant, rural children and adolescents who are residing in the Syrian village of Oyoun Al-Wadi (cf. Ornaghi 2010). The variable (q) is realized in the Arabic variety of Oyoun Al-Wadi and urban varieties such as the ones spoken in Hims and Damascus as shown in Table 1. Children and adolescents are selected for this study for two main reasons. First, they are more likely to adopt incoming urban features and exhibit linguistic change than older speakers in the village. Second, their current linguistic behavior will impact as well as give predictions regarding the future linguistic behavior and trajectory of the village's variety.

\footnotetext{
Variable Variants in the speech of speakers from Oyoun Al-Wadi Variants in urban varieties

(q) [q] [?] [b] ${ }^{*} \quad$ [?]

* The [в] variant, the voiced uvular fricative, rarely occurs; thus, its tokens are excluded in this study. Table 1. Realization of the variable (q) in Oyoun Al-Wadi and urban varieties.
}

The study shows that a bidirectional linguistic change is taking place in the village. Girls continue to use their initially acquired mothers' urban feature in their preadolescent and adolescent years, whereas boys who initially acquired and used their mothers' urban feature start switching to the village's feature around the fourth grade (i.e. age eight or nine) and increase their use of this feature with age. The study also shows that the observed variation and changes result from the different meanings associated with the urban and rural sounds under investigation, and that these variation and changes are not only gender-related but also age-related (Kerswill 1996). The study 
also shows that the kids' emotional involvement in building a social identity starts in preadolescence, indicating early linguistic maturity and sociolinguistic competence.

1.1. Examples of the observed variation-[q] vs. [?]

(1) $\hbar a r q \sim \hbar a r ? \quad$ 'burning'

(2) waqt $\sim$ wapt 'time'

(3) qabl Pabl 'before'

\subsection{Research questions}

In light of the observed variation in the speech of rural children and adolescents in the Syrian village of Oyoun Al-Wadi, the study seeks to answer the following research questions:

1. What are the linguistic patterns of use of the variable $(q)$ in the speech of rural, non-migrant children and adolescents in the village of Oyoun Al-Wadi?

2. What social factors influence the use of the variable $(q)$ ?

3. What could the linguistic behavior of the children and adolescents in the village of Oyoun Al-Wadi inform us about the sociolinguistic situation in the village?

\subsection{Background}

Many sociolinguists investigated variation in urban and suburban centers and in the speech of rural migrants to urban centers (e.g. Amara 2005; Gal 1978; Habib 2005, 2008, 2010a, 2010b, 2010c, 2010d, 2011a, 2011b; Hachimi 2007; Kerswill 1993; Miller 2005). Very few studies dealt with language variation in a rural setting (Hazen 2002; Ornaghi 2010; Walters 1989, 1992). Regarding Arabic dialects, rarely any sociolinguistic study touched on variation and change in child and adolescent language. Al-Wer (2007: 62 ), in her study of the formation of a dialect in the city of Amman in Jordan, included 20 participants, some of which are adolescents, in a young age group to compare their linguistic behavior to their parents and grandparents. Although the youngest speaker in 
the study, and thus in the young age group, was 12 , the age range in this group could be very wide and may include many participants in their twenties. This is assumed because Al-Wer (2007: 63) indicated that six other participants aged 17-20 were added to the sample, indicating that the young age group not only included adolescents but also postadolescents and adults, all of which are the children and grandchildren of the two older age groups, the parents and the grandparents. The latter has a speaker whose age is 78 , indicating that some of the parents could be in their fifties and their children in their late twenties or thirties.

Other studies mainly investigated children's acquisition of certain dialectal phonological patterns when they migrate from their home country or area to a new country or area (e.g. Chambers 1992; Kerswill 1996; Kerswill \& Williams 2000; Payne 1980; Tagliamonte \& Molfenter 2007). These studies indicated that child's acquisition of a second dialect feature depends on the linguistic level, the complexity of the rules involved, and the age of the child (Chambers 1992; Kerswill 1996: 199; Payne 1980). Most of these studies indicated that most grammatical rules are acquired by children by the age of 6 or 7 when children start asserting themselves. For example, Payne (1980) found the age of arrival to the Philadelphia suburb, King of Prussia, played a significant role in the children's second dialect acquisition. For her, eight is the cut-off age, i.e. at age eight or after this age, it is hard for children to master a new form especially grammatically complex ones. Similarly, Chambers (1992) found that Canadian children younger than eight were more adaptive to the British forms than older kids were. Kerswill \& Williams (2000) presented the case of a child, James, who at age 4 talked like his mother. By age 6 , he started talking like his peers, which suggests age-grading linguistic behavior among children (Kerswill \& Williams 2000: 109). Thus, previous research has shown that children initially adopt their caregiver's language, and that the influence of other adults and children increases gradually (e.g. Kerswill 1996; Stanford 2008). With time, children's speech becomes more like that of their peers (Kerswill 1996: 192; Kerswill \& Williams 2000: 97; Stanford 2008).

In addition, many previous studies emphasized that adolescents use linguistic variation to negotiate meaning, social relationships, and identities, and are significant bearers of language change (e.g. Eckert 1988, 1991; Jørgensen 2003; Kerswill 1996: 
198). Kerswill \& Williams (2000) indicated that because the identity of migrant adults is more fixed than that of children who are characterized with a developing social identity, children are more motivated than adults to change their speech along their life course, moving away in adolescence from their caregivers' dialect. Very few studies indicated the role of preadolescents as leaders of linguistic change (Turell 2003: 7). However, some studies showed that children are capable of evaluating language and manipulating language from a very young age for various purposes. For example, Nesdale \& Rooney (1996) indicated that children evaluate language use from preschool age and these evaluative responses increase with age. Similarly, Bolonyai (2005) presented a case in which preadolescent girls use strategic and meaningful linguistic choices or codeswitches between English and Hungarian to achieve distinction, dominance, and power. Stanford (2008) showed children's orientation at a very young age to the variety of their father's clan even when spoken to in their mother's matrilect. The reason for this patrilectal orientation is their early orientation to the identity of their father's clan and being subject to ridicule, admonishment, laughter, and gossip if they use the matrilect variety.

In light of the reviewed literature, the current study aims to fill a major gap in Arabic dialectology studies, i.e. the study of the linguistic behavior of Arab children and adolescents and its expected influence on the general future linguistic behavior of their respective Arab communities. The study also partially attempts to fill a gap that exists in presenting "the emerging social meaning of child variation within the family and peer group interactional setting" (Roberts 2004: 344). It also adds to the meager sociolinguistic variationist studies in rural areas compared to the great number of studies done on urban dialects and urban centers in the Arab world and elsewhere.

\section{Location, population, and history of Oyoun Al-Wadi}

Oyoun Al-Wadi is a majority Christian village administratively under the city of Hims that is in the mid-west of Syria. It is located in the north west of the Hims Governorate to the west of the city of Hims and on the border of the Tartus 
Governorate in the southern part of the Alawite Mountains (Jabour 2010). To the west of it is the small town (originally village) of Mashta Al-Helou; to the east are the villages of Al-Jwaikhat and Trez. The whole area is a tourism area to which visitors from all over the country and from other countries come to enjoy nature and the fresh, cooler air of the mountains in the summer, which makes the village subject to dialect contact. The village's name which means 'The Springs of the Valley' is derived from the numerous running fresh water springs in the village. The population of the village according to the 2005 statistics of the civil registration bureau is 2600 (collected and presented on www.Mshtawy.com by Zakhour Shahem, a recently deceased Mayor of Oyoun AlWadi). ${ }^{+}$However, due to internal and external migration, this number is expected to be much lower especially in the winter.

This village constitutes a good focal point for investigation as the village has seen many changes in the past three to four decades due to external immigration and internal migration. External immigration to Western countries, particularly the Americas, started towards the end of the $19^{\text {th }}$ century and the first third of the $20^{\text {th }}$ century. Internal migration to urban centers particularly to Damascus and Hims was rare until 1939. After 1939, it increased slightly. However, in the late sixties and early seventies, internal migration increased tremendously. In recent years, commuting between rural and urban centers has become easier and more frequent. More rural people live in urban centers, and thus one would have more frequent contact with relatives who live in urban centers. In addition, more people are seeking education and jobs in urban centers, which is conducive to contact with urban dialects. Thus, the village is currently in a transformational period, which makes it a very hot spot for investigating language variation and change. It also fits as a model for other language variations and changes that are going on in other rural areas in Syria, the Arab World, and other parts of the world.

In addition, the village has a rich history that is related to the present linguistic behavior of speakers, particularly males. The father of Oyoun Al-Wadi, Sabiq Suleiman Ma'louf from whom most of the village people descend, migrated from the village Kafr 'Oqab now in Lebanon and settled in Oyoun Al-Wadi in Syria in A.D. 1700. Another

\footnotetext{
${ }^{+}$www.Mshtawy.com is the website of the neighboring town, Mashta Al-Helou.
} 
family came and settled in the village around A.D. 1810, and after the mid of the $19^{\text {th }}$ century, a few more families came and settled in Oyoun Al-Wadi. When Sabiq Ma'louf arrived to Oyoun Al-Wadi, it was called Oyoun 'Affan 'The Springs of 'Affan' after its Agha's name, 'Affan Agha, by the Turkmens who owned and ruled the area. Turkmens are Turkish tribes that lived in Turkmenistan and neighboring areas in Iran and Afghanistan. They entered Syria with the Ottoman Conquests, settling in some of its areas among which is Oyoun Al-Wadi. Around A.D. 1750, The Turkmens fought among themselves and left the area of Oyoun Al-Wadi, Mashta Al-Helou, Al-Jwaikhat, and Trez under the management of Sabiq Ma'louf who was known for his intelligence, bravery, and strength. He was an agent for the Agha, distributing land on farmers, collecting harvests, and marketing them. The sons and grandchildren of Sabiq Ma'louf were also known for their chivalry, ferocity, and toughness (Ma'louf 1978). These characteristics/values of the father of the village and his sons persist in the mentality of males in the village and continue to play a role in their present time everyday behavior, including their linguistic behavior.

Illiterate people are rare in the village in the present day. The first primary school was opened in the village in 1926 . The first secondary school in the whole countryside of Syria was established in the neighboring village Mashta Al-Helou in 1948 by Dr. Hanna Ma'louf who is from the village of Oyoun Al-Wadi (Al-Ma'louf 2008). Before establishing this secondary school, high school education was a dream. Before the mid of the $20^{\text {th }}$ century, electricity and paved roads were limited to cities (Habib 2010b: 69). In Oyoun Al-Wadi, water and electricity were connected to homes in 1963 and 1965 respectively. The spread of private and public secondary schools led to increase in education and more people seeking and obtaining university degrees. This in its turn led to major migration waves to cities to improve one's lifestyle and financial situation through obtaining white-collar jobs instead of working in the farm. In other words, the increase of education led to economic, social, and health development. However, despite the large number of internal migration and external immigration, the people of Oyoun AlWadi retain their pride in their beautiful village and their impetuous demeanor, and maintain very strong ties with their roots, families, and relatives in the village. Their sense of belonging to the village is unbeatable. 
This strong sense of belonging to their village is also reflected in their behavior towards and relations with neighboring villages. It is worth noting the historical animosity between Mashta Al-Helou and Oyoun Al-Wadi that goes back to A.D. 1879 when a fight broke over the ownership of a land between the two villages (called AlQash'at). The fight continued between the two parties until it was resolved by endowing Mashta Al-Helou with the church that belonged to Oyoun Al-Wadi and located on the border of Mashta Al-Helou. This action led to harsh feelings, and fights were repeated at every visit to the church. The fights were sometimes bloody in that once two were killed from each side. Those uneasy feelings between the two villages continue to the present day. This is reflected in the linguistic differences between the two villages. While contact between two varieties over the years often results in similarities between the two, in the case of Oyoun Al-Wadi and Mashta Al-Helou, the two varieties grew apart. The main difference between the two varieties is that the voiceless uvular stop ( $q$ ) is produced as

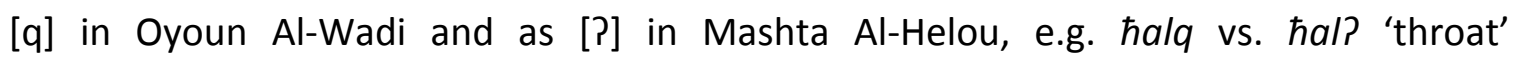
respectively. This history between Oyoun Al-Wadi and Mashta Al-Helou will explain the present day conflict even among the younger generation of children and adolescents regarding the use of [q] and [?] particularly among boys.

It is also worth noting that in the past, marrying non-local women was rare. When a new woman came to the village, she would be criticized if her dialect did not contain the [q] sound (Al-Ma'louf 2008: 93). In the last twenty to twenty-five years, marriage to non-local women became much more common. It could actually be described as a major trend in the village. According to a knowledgeable person from Oyoun Al-Wadi, Jamil Habib (personal communication, 2010), the number of non-local married women is 435; the number of local married women is about 90 . This means that in the present day, the number of out-of-town married women is about five times the number of local married women. This trend of marrying women from outside the village also led women from the village to marry men outside the village. The number of local women married to men outside the village is 377 (Jamil Habib, personal communication, 2010). This increase in marrying women and men from outside the village is not surprising given the increased migration to urban areas in the late sixties and early seventies (Habib 2010b). Seeking higher education and jobs in the city increased contact with urban people and 
rural people who came to the city for similar purposes. This increased personal contact led to relationships with people from outside the village, and thus marriage to those people. Hence, the current family situation in the village is much more diverse than it was 25-30 years ago. In the past, village people mainly communicated with each other while working and playing in their farms, shepherding the cattle, or harvesting crops. Thus, they had minor contact with outsiders. Consequently, they fell in love with each other and got married.

\section{Methodology and data}

\subsection{Speech sample and data collection}

The speech sample consists of the naturally occurring speech of 50 speakers aged 6-18. Speakers were recorded during spring 2010 in the village of Oyoun Al-Wadi. The author went initially to the village's schools to observe classes to familiarize children and adolescents with her. She also observed whether the teachers' dialects were influential in the classroom. She was able to collect in the classrooms the contact numbers of the students' parents to obtain their permission to interview and record their children. Schools, teachers, and parents were very helpful and showed great willingness to allow their children to participate in the project. Some of the parents and teachers volunteered information themselves and were willing to participate in the project themselves. Some recordings took place at the parents' home. However, it was preferable to carry the interviews in the author's home after experiencing great difficulty and sound clarity problems at the parents' home. It is common in the village's culture for visitors to come unexpectedly and interrupt interviews or talk during the interview, which would make the sound quality very poor. Thus, parents were asked if possible to send their children to the author's home. They were happy and willing to do so.

Data collection was carried out in naturalistic settings to elicit the most natural speech from participants. The interviews, conducted in the presence of family members 
or friends, included initially gathering personal information. Information solicited concerned the child; his parents; extended family; linguistic features and varieties used by family members, friends, classmates, teachers and relatives; connection to urban centers and people living in urban centers; degree of contact with speakers that use urban features; and TV programs watched and hours spent watching programs that contain the linguistic features under investigation. The informal interviews lasted between 30-45 minutes with each individual speaker. A high quality digital recorder (marantz Professional Solid State Recorder PMD660) was used with a built-in microphone to record the interviews. The built-in microphone was used to avoid drawing the participants' attention to the recorder, and thus to elicit the most naturalistic speech possible. During the interviews, children and adolescents were asked to tell stories or jokes or talk about some event or story that affected them, their friends, their family, or others or they heard recently in the news or from acquaintances.

The choice of the village Oyoun Al-Wadi was based on a number of reasons (Section 2). In relation to data collection, two reasons play significant roles in obtaining the most naturalistic and suitable data for the study. First, the author is familiar with the village and its culture and acquainted with the variety spoken in the village. Second, she is an in-group member that allowed her to integrate easily into the community, obtain the most naturalistic data, and compile abundant information about the participants, their families, their practices, their likes and dislikes, the societal and cultural changes that are taking place, etc.

\subsection{Social factors}

The social factors that are taken into consideration in this study are gender, age, mother's origin, and area of residence. Gender is divided equally into 25 males and 25 females. The sample is divided into four age groups that are almost equally divided regarding the number of participants and the number of girls and boy in each group. The youngest age group contains 12 speakers aged six to eight, of which six are girls and six are boys. The second age group contains 13 speakers aged nine to eleven, of which six are girls and seven are boys. The third age group contains 13 speakers aged 12 to 14 , of 
which seven are girls and six are boys. The oldest age group contains 12 speakers aged 15 to 18 , of which six are girls and six are boys. There are 12 mothers from Oyoun AlWadi and 38 mothers from outside Oyoun Al-Wadi. This is not surprising given the large difference in the number of married women from Oyoun Al-Wadi and from outside Oyoun Al-Wadi. As for area of residence, 31 speakers come from I-Hara I-Fu[?]/[q]aniyyi 'the Upper Quarter'; 15 speakers come from I-Hara t-Tiht[a:]/[e:]niyyi 'the Lower Quarter'; and four speakers come from Harit I-Madraj 'the Downhill Quarter'. Table 2 shows the social distribution of the study participants.

It is worth noting that there is also a kind of challenge between the Lower Quarter and Upper Quarter. The people from the Lower Quarter think that they are more sophisticated than the people of the Upper Quarter even in their speech, i.e. they are more urbanized and use more urban features in their speech. They even call the Upper Quarter I-rif 'the countryside/the village' and they call the Lower Quarter I-madini 'the city'. In reality, no major difference is observed between the two quarters, as the quantitative results will show (Sections $4.2 \& 4.3$ ). They are mainly perceptive differences based on subjective feeling of superiority, even though the people from the Upper Quarter seem to acquire more wealth and own more land in the village than people from the Lower Quarter.

\subsection{Data}

Table 3 shows the distribution of [q], [?], and [ $\mathrm{k}]$ in the speech of the 50 participants. It shows that there is a general tendency towards the use of the urban form [?] with $78 \%$ use of [?] compared to $21 \%$ use of [q]. The use of [ $\mathrm{k}$ ] is insignificant, as it constitutes less than $1 \%$. However, comparing the linguistic behavior of boys and girls across the different age groups reveals the following: (1) boys and girls behave similarly in the youngest age group (Table 4); and (2) girls maintain their use of the urban form throughout their preadolescence and adolescence, while boys show higher percentages of the rural form from age nine and up (Table 4). Table 4 shows that in the age groups 9$11,12-14$, and 15-18 three out of seven boys, four out of six boys, and three out of six boys respectively use very high percentages of [q]. 


\begin{tabular}{|c|c|c|c|c|c|c|}
\hline \# & Name & Age & Grade & Gender & Mother's Origin & Area \\
\hline 1 & 'Adan & 6 & $1^{\mathrm{st}}$ & M & $\begin{array}{l}\text { Not from Oyoun Al-Wadi } \\
\text { (NFO) }\end{array}$ & Upper Quarter (UQ) \\
\hline 2 & $\operatorname{Max}$ & 6 & $1^{\text {st }}$ & M & NFO & UQ \\
\hline 3 & Shama & 6 & $1^{\text {st }}$ & $\mathrm{F}$ & NFO & UQ \\
\hline 4 & Sandy & 6 & $1^{\text {st }}$ & $\mathrm{F}$ & NFO & UQ \\
\hline 5 & Jerjes & 7 & $2^{\text {nd }}$ & M & NFO & UQ \\
\hline 6 & Rico & 7 & $2^{\text {nd }}$ & M & NFO & UQ \\
\hline 7 & Halab & 7 & $2^{\text {nd }}$ & $\mathrm{F}$ & NFO & UQ \\
\hline 8 & Jessy & 8 & $3^{\text {rd }}$ & $\mathrm{F}$ & NFO & LQ \\
\hline 9 & Talia & 8 & $3^{\text {rd }}$ & $\mathrm{F}$ & From Oyoun Al-Wadi (FO) & LQ \\
\hline 10 & Neomi & 8 & $3^{\text {rd }}$ & $\mathrm{F}$ & FO & LQ \\
\hline 11 & Eli & 8 & $3^{\text {rd }}$ & M & NFO & LQ \\
\hline 12 & 'Anis & 8 & $4^{\text {th }}$ & M & NFO & UQ \\
\hline 13 & Dani & 9 & $3^{\text {rd }}$ & $M$ & NFO & UQ \\
\hline 14 & Ward & 9 & $3^{\text {rd }}$ & M & FO & LQ \\
\hline 15 & Rula & 9 & $3^{\text {rd }}$ & $\mathrm{F}$ & NFO & UQ \\
\hline 16 & Lina & 9 & $4^{\text {th }}$ & $\mathrm{F}$ & NFO & LQ \\
\hline 17 & Jorgos & 9 & $4^{\text {th }}$ & M & FO & Downhill Quarter (DQ) \\
\hline 18 & Mary & 10 & $5^{\text {th }}$ & $\mathrm{F}$ & NFO & UQ \\
\hline 19 & Margaret & 10 & $5^{\text {th }}$ & $\mathrm{F}$ & NFO & LQ \\
\hline 20 & Jabour & 10 & $5^{\text {th }}$ & $M$ & NFO & UQ \\
\hline 21 & Rami & 11 & $5^{\text {th }}$ & $M$ & FO & LQ \\
\hline 22 & Lu’ai & 11 & $6^{\text {th }}$ & $M$ & NFO & UQ \\
\hline 23 & Jano & 11 & $6^{\text {th }}$ & $M$ & NFO & UQ \\
\hline 24 & Jenny & 11 & $6^{\text {th }}$ & $\mathrm{F}$ & NFO & UQ \\
\hline 25 & Rasha & 10 & $6^{\text {th }}$ & $\mathrm{F}$ & NFO & UQ \\
\hline 26 & Fuad & 12 & $7^{\text {th }}$ & $M$ & NFO & $\mathrm{DQ}$ \\
\hline 27 & Naji & 13 & $7^{\text {th }}$ & $M$ & NFO & UQ \\
\hline 28 & Salina & 13 & $7^{\text {th }}$ & $\mathrm{F}$ & FO & LQ \\
\hline 29 & Rouda & 13 & $7^{\text {th }}$ & $\mathrm{F}$ & FO & LQ \\
\hline 30 & Rachel & 13 & $8^{\text {th }}$ & $\mathrm{F}$ & FO & LQ \\
\hline 31 & Randa & 13 & $8^{\text {th }}$ & $\mathrm{F}$ & NFO & UQ \\
\hline 32 & Roma & 13 & $8^{\text {th }}$ & $\mathrm{F}$ & NFO & LQ \\
\hline 33 & Imad & 13 & $8^{\text {th }}$ & $M$ & NFO & UQ \\
\hline 34 & Rojer & 14 & $8^{\text {th }}$ & $M$ & FO & $\mathrm{DQ}$ \\
\hline 35 & Husam & 14 & $8^{\text {th }}$ & $M$ & NFO & UQ \\
\hline 36 & Rada & 14 & $9^{\text {th }}$ & $\mathrm{F}$ & NFO & UQ \\
\hline 37 & Wardi & 14 & $9^{\text {th }}$ & $\mathrm{F}$ & FO & $\mathrm{DQ}$ \\
\hline 38 & Maher & 14 & $9^{\text {th }}$ & $M$ & NFO & UQ \\
\hline 39 & Ola & 15 & $10^{\text {th }}$ & $\mathrm{F}$ & NFO & UQ \\
\hline 40 & Salam & 15 & $10^{\text {th }}$ & $\mathrm{F}$ & NFO & UQ \\
\hline 41 & Peter & 15 & $10^{\text {th }}$ & $M$ & FO & LQ \\
\hline 42 & Andy & 16 & $10^{\text {th }}$ & $M$ & NFO & UQ \\
\hline 43 & Nariman & 16 & $11^{\text {th }}$ & $\mathrm{F}$ & NFO & UQ \\
\hline 44 & Rimona & 16 & $11^{\text {th }}$ & $\mathrm{F}$ & NFO & UQ \\
\hline 45 & Miller & 16 & $11^{\text {th }}$ & $M$ & FO & LQ \\
\hline
\end{tabular}


Dialectologia 16 (2016), 117-141.

ISSN: 2013-2247

\begin{tabular}{lllllll}
\hline 46 & 'Atif & 17 & $11^{\text {th }}$ & M & NFO & UQ \\
47 & Naseem & 17 & $12^{\text {th }}$ & M & NFO & UQ \\
48 & Kamal & 18 & $12^{\text {th }}$ & M & NFO & LQ \\
49 & Hala & 17 & $12^{\text {th }}$ & F & NFO & UQ \\
50 & Ghada & 17 & $10^{\text {th }}$ & F & NFO & UQ \\
\hline
\end{tabular}

Table 2. Social distribution of the study participants.

\begin{tabular}{|c|c|c|c|c|c|c|c|c|}
\hline$\#$ & Name & [q] & $\%$ & [?] & $\%$ & [в] & $\%$ & Total \\
\hline 1 & 'Adan & 0 & 0 & 38 & 100 & 0 & 0 & 38 \\
\hline 2 & Max & 0 & 0 & 49 & 100 & 0 & 0 & 49 \\
\hline 3 & Shama & 0 & 0 & 136 & 100 & 0 & 0 & 136 \\
\hline 4 & Sandy & 1 & 0.5 & 191 & 99.5 & 0 & 0 & 192 \\
\hline 5 & Jerjes & 3 & 4 & 69 & 96 & 0 & 0 & 72 \\
\hline 6 & Rico & 1 & 2 & 42 & 98 & 0 & 0 & 43 \\
\hline 7 & Halab & 8 & 13 & 52 & 87 & 0 & 0 & 60 \\
\hline 8 & Jessy & 3 & 3 & 103 & 97 & 0 & 0 & 106 \\
\hline 9 & Talia & 18 & 20 & 73 & 80 & 0 & 0 & 91 \\
\hline 10 & Neomi & 11 & 17 & 51 & 81 & 1 & 2 & 63 \\
\hline 11 & Eli & 5 & 5 & 100 & 94 & 1 & 1 & 106 \\
\hline 12 & 'Anis & 2 & 2 & 96 & 98 & 0 & 0 & 98 \\
\hline 13 & Dani & 3 & 6 & 46 & 94 & 0 & 0 & 49 \\
\hline 14 & Ward & 5 & 4 & 125 & 96 & 0 & 0 & 130 \\
\hline 15 & Rula & 7 & 9 & 72 & 91 & 0 & 0 & 79 \\
\hline 16 & Lina & 0 & 0 & 77 & 100 & 0 & 0 & 77 \\
\hline 17 & Jorgos & 62 & 89 & 8 & 11 & 0 & 0 & 70 \\
\hline 18 & Mary & 7 & 4 & 177 & 96 & 0 & 0 & 184 \\
\hline 19 & Margaret & 13 & 14 & 79 & 86 & 0 & 0 & 92 \\
\hline 20 & Jabour & 35 & 27 & 95 & 73 & 0 & 0 & 130 \\
\hline 21 & Rami & 113 & 46.5 & 123 & 50.5 & 7 & 3 & 243 \\
\hline 22 & Lu'ai & 84 & 97 & 3 & 3 & 0 & 0 & 87 \\
\hline 23 & Jano & 4 & 4 & 106 & 96 & 0 & 0 & 110 \\
\hline 24 & Jenny & 7 & 7 & 88 & 93 & 0 & 0 & 95 \\
\hline 25 & Rasha & 1 & 2 & 50 & 98 & 0 & 0 & 51 \\
\hline 26 & Fu'ad & 102 & 100 & 0 & 0 & 0 & 0 & 102 \\
\hline 27 & Naji & 2 & 2 & 107 & 98 & 0 & 0 & 109 \\
\hline 28 & Salina & 4 & 3 & 117 & 97 & 0 & 0 & 121 \\
\hline 29 & Rouda & 0 & 0 & 89 & 100 & 0 & 0 & 89 \\
\hline 30 & Rachel & 19 & 19 & 83 & 81 & 0 & 0 & 102 \\
\hline 31 & Randa & 1 & 1 & 114 & 92.5 & 8 & 6.5 & 123 \\
\hline 32 & Roma & 2 & 1 & 213 & 99 & 0 & 0 & 215 \\
\hline 33 & Imad & 72 & 89 & 8 & 10 & 1 & 1 & 81 \\
\hline 34 & Roger & 37 & 95 & 1 & 2.5 & 1 & 2.5 & 39 \\
\hline 35 & Husam & 9 & 21 & 34 & 79 & 0 & 0 & 43 \\
\hline 36 & Rada & 10 & 11.4 & 76 & 86.4 & 2 & 2.2 & 88 \\
\hline 37 & Wardi & 40 & 95 & 2 & 5 & 0 & 0 & 42 \\
\hline 38 & Maher & 104 & 86 & 16 & 13 & 1 & 1 & 121 \\
\hline
\end{tabular}




\begin{tabular}{lllllllll}
\hline 39 & Ola & 1 & 1 & 159 & 99 & 0 & 0 & 160 \\
40 & Salam & 54 & 25 & 166 & 75 & 0 & 0 & 220 \\
41 & Peter & 47 & 82 & 10 & 18 & 0 & 0 & 57 \\
42 & Andy & 16 & 28 & 42 & 72 & 0 & 0 & 58 \\
43 & Nariman & 9 & 5 & 167 & 95 & 0 & 0 & 176 \\
44 & Rimona & 9 & 14 & 54 & 86 & 0 & 0 & 63 \\
45 & Miller & 29 & 43 & 36 & 53 & 3 & 4 & 68 \\
46 & 'Atif & 1 & 1 & 82 & 99 & 0 & 0 & 83 \\
47 & Naseem & 9 & 8 & 106 & 92 & 0 & 0 & 115 \\
48 & Kamal & 116 & 97 & 4 & 3 & 0 & 0 & 120 \\
49 & Hala & 1 & 1 & 152 & 99 & 0 & 0 & 153 \\
50 & Ghada & 0 & 0 & 149 & 99 & 1 & 1 & 150 \\
& Total & 1087 & 21 & 4036 & 78 & 26 & 1 & 5149 \\
\hline
\end{tabular}

Table 3. Distribution of [q], [?], and [b] in the speech of the participants.

All other speakers use percentages of [q] that range between $0-28 \%$, with the higher percentages used by boys. This indicates that girls show higher tendency towards the use of the urban form than boys do. There is a clear shift in their speech towards the urban form [?]. On the other hand, boys show more inter-speaker variation and greater tendency towards the rural form. About half of the boys use more [q] than [?] in the three older age groups.

\begin{tabular}{llll}
\hline Age group & Girls' behavior & Boys' behavior & Details \\
\hline $6-8$ & Mainly [?] & Mainly [?] & No difference \\
\hline $9-11$ & Mainly [?] & 3/7 boys use high percentage of [q] & $\begin{array}{l}\text { Jorgos }\left(4^{\text {th }} \text { grade, } 9\right)=89 \% \\
\text { Rami }\left(5^{\text {th }} \text { grade, } 11\right)=46.5 \% \\
\end{array}$ \\
& & & Lu'ai $\left(6^{\text {th }}\right.$ grade, 11$)=97 \%$ \\
\hline $12-14$ & Mainly [?] & $4 / 6$ boys use high percentage of [q] & Fu'ad $\left(7^{\text {th }}\right.$ grade, 12$)=100 \%$ \\
& & Imad $\left(8^{\text {th }}\right.$ grade, 13$)=89 \%$ \\
& & & Roger $\left(8^{\text {th }}\right.$ grade, 14$)=95 \%$ \\
& & & Maher $\left(9^{\text {th }}\right.$ grade, 14$)=86 \%$ \\
\hline $15-18$ & Mainly [?] & $3 / 6$ boys use high percentage of [q] & Peter $\left(10^{\text {th }}\right.$ grade, 15$)=82 \%$ \\
& & & Miller $\left(11^{\text {th }}\right.$ grade, 16$)=43 \%$ \\
& & Kamal $\left(12^{\text {th }}\right.$ grade, 18$)=97 \%$ \\
\hline
\end{tabular}

Table 4. Gender and age groups differences in the use of [q] and [?]

\section{Quantitative analysis and results}

The Statistical Package for Social Sciences (SPSS) is used to perform the statistical analysis. A binary logistic regression test is carried out to investigate the main effects of 
the social factors, gender, age, mother's origin, and area of residence, on the use of each of the linguistic variable (q). The results are reported in the following sections. In this study, the variant [ $в$ ] (Tables $1 \& 3$ ) is excluded from the quantitative analysis because of its very limited occurrence in the speech of the 50 participants. Eliminating it will not affect the statistical results.

\subsection{Distribution of variants according to the social factors under investigation}

The distribution of the variants according to gender reveals that girls use the urban form more than boys (Figure 1). The distribution of variants according to age shows that age groups vary considerably in their use of [q] and [?] (Figure 2). Figure 2 shows that the youngest age group uses [?] the most. This use decreases with age. It reaches its lowest point in the age group 12-14. In contrast, the use of [q] increases with age and reaches its highest point in the age group 12-14. This is not surprising given that four out of six boys in this age group use very high percentages of [q] and almost no [?]. The use of [?] increases slightly in the oldest age group but remains at a much higher level than the youngest age group. The pattern in Figure 2 indicates a change in progress towards the rural form. The distribution of variants based on whether the speaker's mother is from Oyoun Al-Wadi or not reveals some difference (Figure 3). The distribution of variants according to the area of residence shows there is no noticeable difference between the residents of the Upper and Lower Quarters (Figure 4). However, the difference is great between these two Quarters and the Downhill Quarter. The residents of this Quarter have almost $100 \%$ use of [q] and almost no use of [?]. This is because the Downhill quarter is somehow isolated from the rest of the village. Most of the people who live in this Quarter are either pure people from Oyoun Al-Wadi or few Alawite families that settled later in the village and whose speech is characterized with [q] (Habib 2010b: 68). 


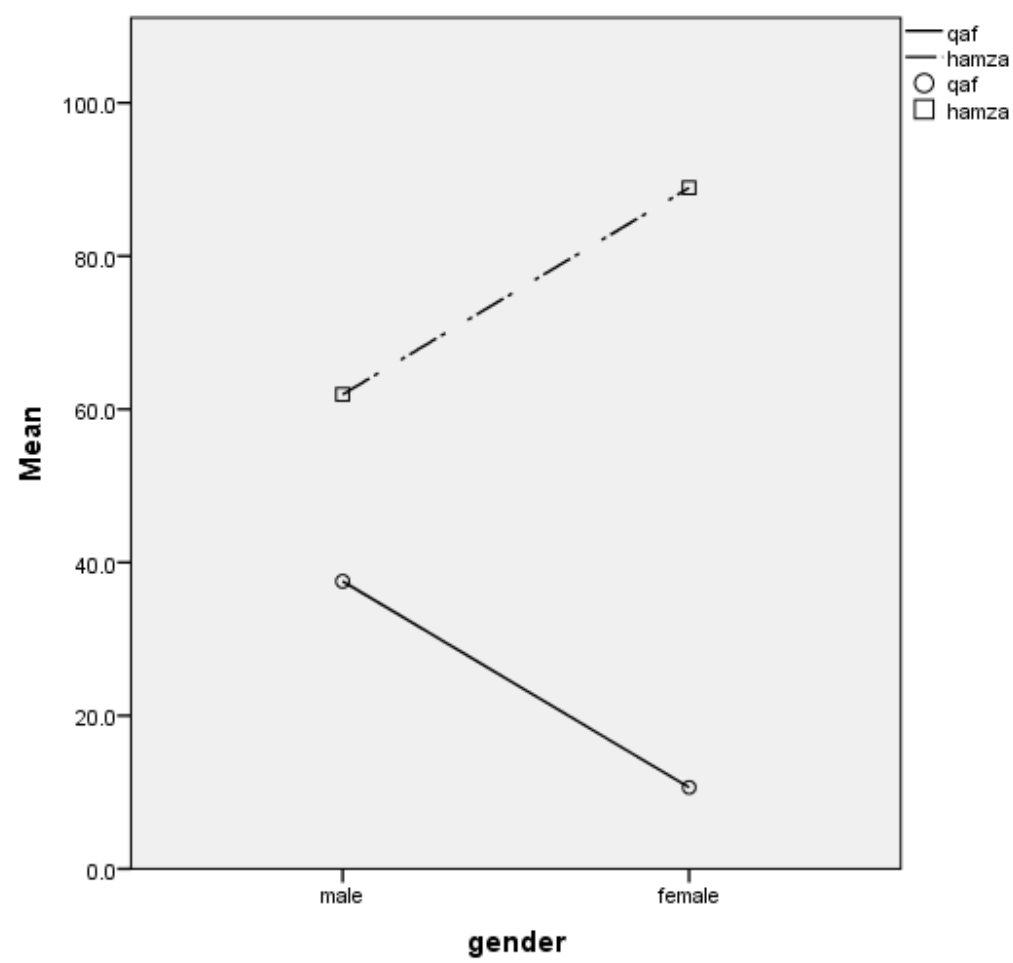

Figure 1. Distribution of [q] and [?] according to gender.

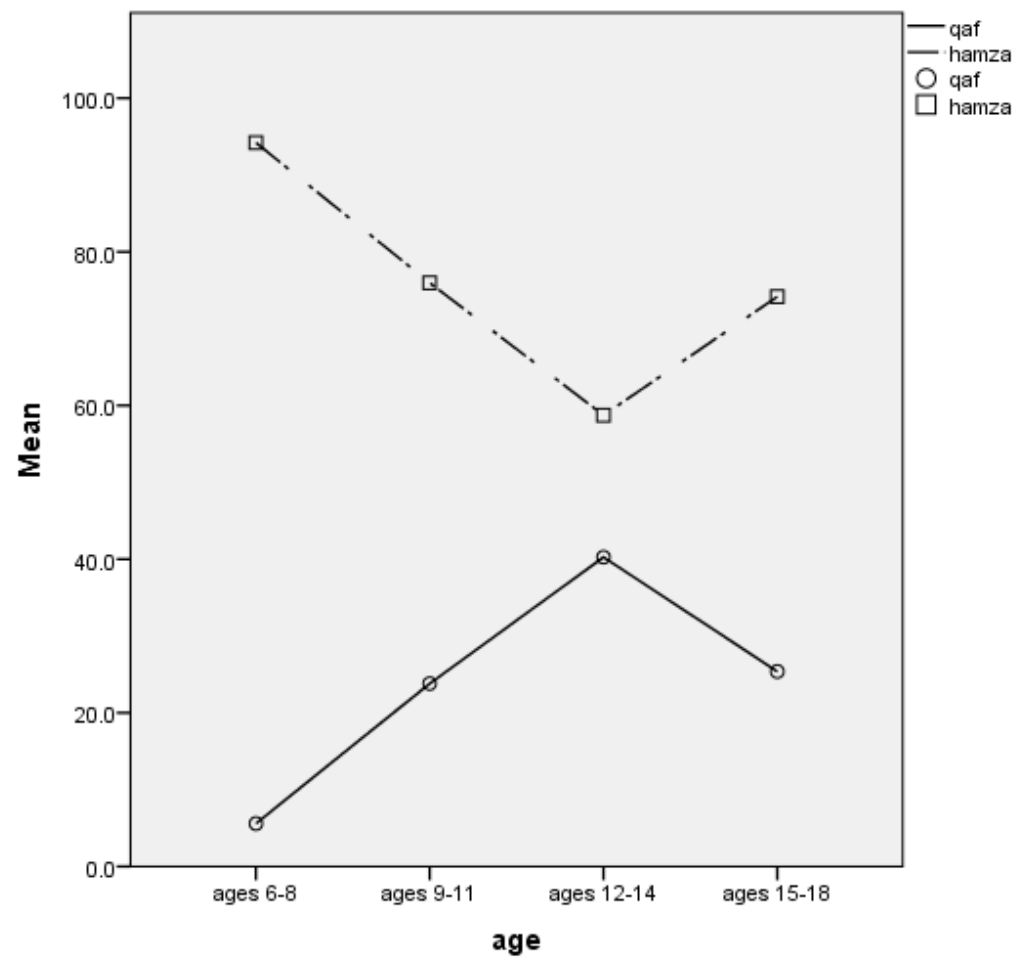

Figure 2. Distribution of [q] and [?] according to age. 
Dialectologia 16 (2016), 117-141.

ISSN: 2013-2247

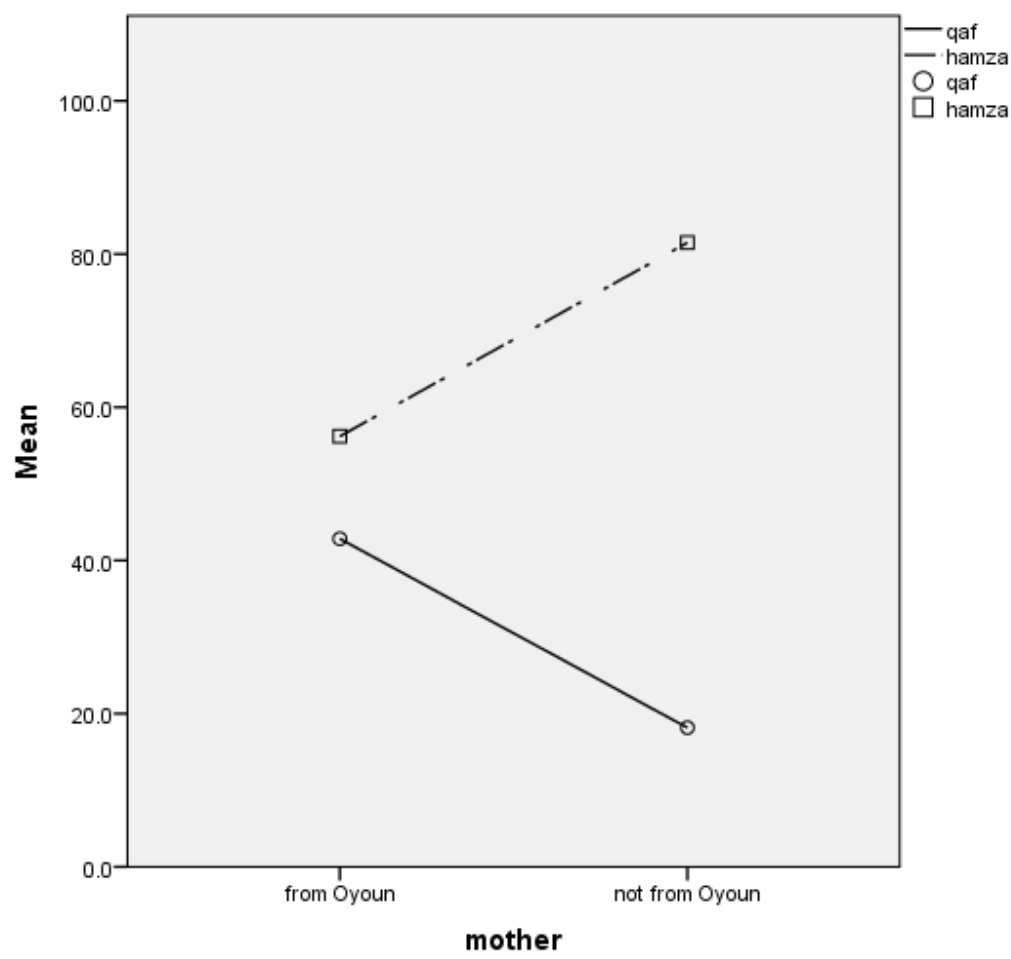

Figure 3. Distribution of [q] and [?] according to mother's origin.

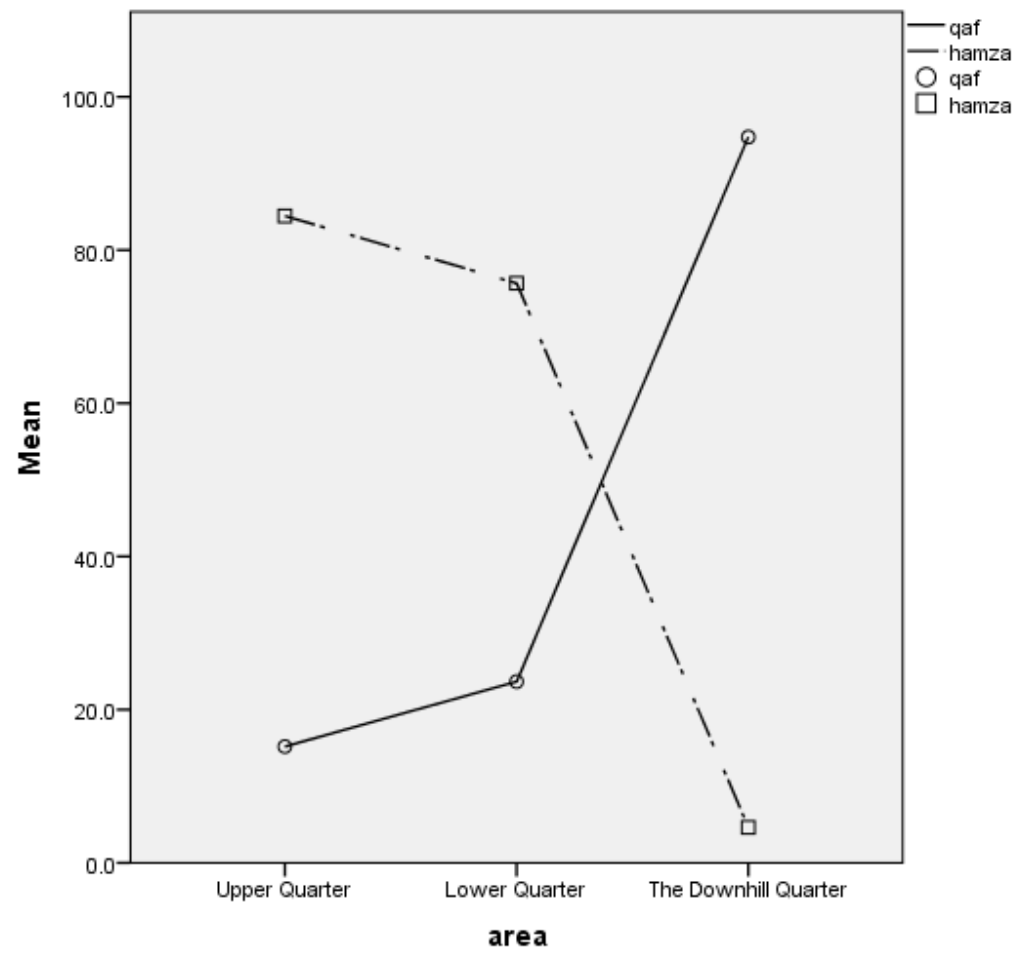

Figure 4. Distribution of [q] and [?] according to area of residence. 


\subsection{Results of the binary logistic regression test}

Table 5 summarizes the results of the binary logistic regression test. The numbers in it represent the $p$-values that are considered significant at $\geq 0.05$. Table 5 shows that gender and area of residence play a significant role. What is interesting is that mother's origin emerges as statistically insignificant; it does not play a role in the observed interand intra-speaker variation in the use of $(q)$. The results in Table 5 can be interpreted as follows based on the coefficients $(B)$ and their exponentials $(\operatorname{Exp}(B))$ in the Parameter Estimate Tables that are not included for space purposes. Only the coefficients and exponentials that show significance are reported here. The odds that males would use the rural sound $[q](p=0.000 ; B=2.134 ; \operatorname{Exp}(B)=8.450)$ are 9 times the odds that females would use it. Although age emerged as statistically insignificant in the Main Effects Table, the Parameter Estimate Table shows that the use of the urban sound [?] by the youngest age group is statistically significant and that the odds that this group would use [?] $(p=0.047 ; B=1.899 ; \operatorname{Exp}(B)=6.679)$ is 7 times the odds that the older age groups would use it. Regarding area of residence, the Parameter Estimate Table also shows statistical significance; the odds that the Upper Quarter $(p=0.022 ; B=4.581$; $\operatorname{Exp}(B)=97.615)$ and the Lower Quarter $(p=0.049 ; B=3.737 ; \operatorname{Exp}(B)=41.992)$ would use the urban sound [?] are respectively 98 times and 42 times the odds that the Downhill Quarter would use it.

\begin{tabular}{ll}
\hline Independent factor & (q) \\
\hline Gender & 0.000 \\
Age & 0.104 \\
Mother's origin & 0.688 \\
Area & 0.006 \\
\hline
\end{tabular}

Table 5. Main Effects of gender, age, mother's origin, and area on the use of the variable (q).

These results indicate obvious gender differences whereby boys use more rural forms than girls. There are also differences between the youngest age group and the three older age groups. The youngest age group uses [?] almost categorically. However, 
the use of [?] decreases and the use of [q] increases in the three older age groups, mainly among boys (Table 4), which could indicate a change in progress initiated by boys in the age group 9-11 and advanced by age group 12-14 (Figure 2). Despite the slight dip in age group 15-18, this group exhibits high usage of [q] comparable to age group 9-11. Some differences also exist among the three areas of residence. Speakers who reside in the Downhill Quarter use more rural forms than speakers residing in the Upper and Lower Quarters.

\subsection{Discussion of results with the help of ethnographic information}

The findings in this study require further explanation through more thorough ethnographic investigation. During the interviews and informal conversations, many male speakers, parents, and siblings mentioned that they noticed themselves, their son(s), or their brother(s) respectively change his/their speech (i.e. started using the [q] sound) towards the fourth or fifth grade, i.e. around eight or nine years of age. A couple of speakers mentioned the third grade, and one sister mentioned that she noticed her brother started changing in the first grade.

The social meanings of the urban and rural variants were also extracted from the interviews. A summary of these extracted social meanings is presented in this paper. Many girls said that they do not like the qaf sound for reasons such as being unpleasant, ugly, harsh, not soft, and old fashion. They feel it is for men and that it requires more effort in pronunciation (i.e., more stress or pressure is used in its pronunciation). For them, qaf is Dai'aje 'rural' and shameful. On the other hand, ?af is nicer, prettier, better, softer, gentler, and more refined for girls. ${ }^{\ddagger}$ ?af is Nahawe 'lit. grammatical, but it refers to the urban form in the village's sense of the word'. Boys and parents also mentioned these reasons to explain why girls use or should use [?]. Some of the younger boys also mentioned these reasons for their use of Paf.

On the other hand, most boys like the qaf sound more for reasons such as manliness, masculinity, immensity, strength, and power. It makes them feel masculine

\footnotetext{
‡ They use the word ?af to indicate hamza, replacing the [q] of qaf with [?] as a convention of their pronunciation of qaf.
} 
like their father. For some, it is more suitable, nicer, and easier (in the sense it comes more natural to them). It makes them feel they belong to the village, as opposed to feeling like strangers. Some of them use it to satisfy the father or spite the mother or to show independence and individuality. The sound [q] gives them a strong feeling of association with their village and represents for them features of manhood in their village: strength, valor, and toughness.

Boys may ridicule other boys if they use ?af, giving each other names such as, Mishtawe (i.e., a person from Mashta Al-Helou) and tant 'lit. aunt, but it is used to mean gay or weak' (cf. Al-Wer 2007: 67), meanings associated with Paf among boys in the village. It is worth noting that some of them associate the word Mishtawe with tant. Thus, accusing someone of being Mishtawe means that one is from Mashta Al-Helou and thus betraying his roots and supporting his adversaries. This is also considered an insult to a boy from Oyoun Al-Wadi because it indicates weakness given the association of Mishtawe with tant and thus weakness. This linguistic reaction of the village's boys is not surprising as ridicule (Stanford 2008) and peer pressure (Romaine 1995: 238) have been indicated as major influences on children's speech and acquisition of another feature or dialect.

However, despite these conflicts we observe some boys move on with their lives careless of what their friends may call them. They maintain extensive use of [?]. This indicates there is a linguistic conflict that results from oppositional forces. These forces work at the intra- and inter-speaker levels. These forces will be called centrifugal forces and centripetal forces. Centrifugal forces refer to the external social forces and the prestige brought about by the urban forms. Centripetal forces refer to the village sense of belonging and male values such as toughness, masculinity, ferocity, etc. Sometimes the centrifugal forces overcome the centripetal forces and vice versa.

In addition, speakers mentioned that the area they grow in or their surrounding environment influences their speech. Some girls mentioned that boys are allowed more freedom of movement than girls are, and thus have more opportunities to communicate with the traditional village people in the street outside their homes. More contact with the village environment and with male friends allows them to use more [q]. On the other hand, girls have less freedom of movement; they stay mostly at home with their 
mothers. Even their contact with their female friends is limited to the homes of each other. Hence, they retain their mothers' form. Furthermore, there are very limited friendships among boys and girls in the village, which limits communication between them as well as mutual linguistic influence.

\section{Conclusion}

The study shows a wide spread of the urban feature among the village's children. However, there seems to be two linguistic trends that are gender- and age-related. The spread of the urban feature is retained in the girls' speech in their preadolescence and adolescence but overturned towards the rural feature in the boys' speech. Boys who, like girls, acquired their out-of-town mothers' feature initially start around the age of eight switching to the village feature because it carries meanings of vigor, bravery, virility, masculinity, and a strong sense of belonging to the village. Girls, on the other hand, are encouraged and continue to use the urban feature because it carries meanings of femininity, softness, delicateness, and refinement. Boys start at the age of eight conceptualizing the various meanings associated with the rural and urban forms and refuse to identify with the latter meanings, abandoning the urban feature and adopting the rural feature around the fourth grade.

Variation in adolescent language has been investigated by many but mainly in urban and suburban areas, indicating that "emotional involvement in social identity" is more salient in adolescence than in any other life stage (Eckert 1988: 206; 1991). The desire to have distinct social identities makes adolescents significant bearers of language change (Eckert 1988, 1991; Kerswill 1996: 198). The present study rather focuses on a rural community and finds that the youth's emotional involvement in building a social identity starts earlier in life than in adolescence (i.e. in pre-adolescence). The boys' desire to have a distinct social identity from girls, i.e. an identity that is charged with masculinity and manliness, emerges as early as eight years of age. In some cases, it starts earlier. This finding is significant because it relates to the age in which children start conceptualizing the social meaning of linguistic variables and implementing this knowledge in their speech. It reflects on the linguistic maturity and 
sociolinguistic competence of kids and their ability to differentiate and choose among linguistic variants at an early stage of their life. These children's linguistic behavior accords with Kerswill's (1996: 181) definition of sociolinguistic competence as "a person's ability to recognize language varieties within the community, to evaluate those varieties socially, and to exploit them in the communication of social meaning."

In this study, it is apparent that the social and psychological development of children and the social meanings development of sounds are concurrent at every stage of their lives. However, this development and gender differentiation process (Labov 2010: 254) is more apparent in boys' than in girls' linguistic behavior because tangible change towards the use of rural forms is observed in their speech in their preadolescent and adolescent years. As soon as they start recognizing the importance of certain sounds to the development of their local and masculine identity, boys deviate from their mothers' form. The fact that girls do not deviate from their mothers' form does not exclude them from this development and gender differentiation process. By retaining their mothers' urban form, girls are announcing their feminine, soft, and more refined status. The development of social meaning in relation to gender differentiation in the girls' case can be gleaned from the story of a 13-year old girl who used the rural forms earlier on in her life because both her parents are from Oyoun Al-Wadi and use rural forms. In her early adolescent years, she adopted the urban form due to friendly, familial, and societal encouragement to sound more refined and soft. The recognition and adoption of norms that are more appropriate for females and males (Walters 1991: 213 ) is a major part of this social and psychological development as well as the gender differentiation process.

Thus, the different social meanings of the urban and rural sounds in this study lead to salient linguistic differences between boys and girls and among boys from different age cohorts, resulting in the acquisition of different features at different stages in their lives and in bidirectional linguistic changes in youth language within the same community. 
Dialectologia 16 (2016), 117-141.

ISSN: 2013-2247

\section{References}

AL-MA'Louf, H. E. (2008) Tariq I-Hayat wa Hayat T-Tariq 'Life Road and Road Life', Hims, Syria: AlSha“ar li-TTiba’a.

AMARA, M. (2005) "Language, migration and urbanization: The case of Bethlehem", Linguistics, $43(5), 883-901$.

Bolonyal, A. (2005) “'Who was the best': Power, knowledge and rationality in bilingual girls' code choices", Journal of Sociolinguistics, 9 (1), 3-27.

ChAMBERS, J. K. (1992) “Dialect Acquisition”, Language, 68, 683-705.

ECKERT, P. (1988) “Adolescent Social Structure and Spread of Linguistic Change", Language in Society, 17, 183-207.

ECKERT, P. (1991) "Social polarization and the choice of linguistic variants", in P. Eckert (ed.), New ways of analyzing sound change, San Diego, CA: Academic Press, 213-232.

AL-WER, E. (2007) "The formation of the dialect of Amman: From chaos to order", in C. Miller, E. Al-Wer, D. Caubet, \& J. C. E. Watson (eds.), Arabic in the city: Issues in dialect contact and language variation, London: Routledge, 55-76.

GAL, S. (1978) "Peasant men can't get wives: Language change and sex roles in bilingual community", Language in Society, 77 (1), 1-16.

HABIB, R. (2005) The Role of Social Factors, Lexical Borrowing and Speech Accommodation in the Variation of [q] and [?] in the Colloquial Arabic of Rural Migrant Families in Hims, Syria, Unpublished master's thesis, University of Florida.

HABIB, R. (2008) New Model for Analyzing Sociolinguistic Variation: The Interaction of Social and Linguistic Constraints, Unpublished doctoral dissertation, University of Florida.

HABIB, R. (2010a) "Towards determining social class in Arabic-speaking communities and implications for linguistic variation", Sociolinguistic Studies, 4(1), 175-200.

HABIB, R. (2010b) "Rural migration and language variation in Hims, Syria", SKY Journal of Linguistics, 23, 61-99.

HABIB, R. (2010c) "Word frequency and the acquisition of the Arabic urban prestigious form [?]", Glossa, 5 (2), 198-219.

HABIB, R. (2010d) “New model for analyzing sociolinguistic variation: Introducing social constraints to Stochastic Optimality Theory", in E. T. Spencer (ed.), Sociolinguistics [Languages and Linguistics Series], Hauppauge, NY: Nova Science Publishers, Inc, 47-97. 
HABIB, R. (2011a) "New model for bilingual minds in sociolinguistic variation situations: Interacting social and linguistic constraints", International Journal of Psychology Research, $6(6), 707-760$.

HABIB, R. (2011b) "Frequency effects and the lexical split in the use of $[t]$ and $[s]$ and $[d]$ and $[z]$ in the Syrian Arabic of Christian rural migrants", Journal of Historical Linguistics, 1 (1), 77-105. HACHIMI, A. (2007) "Becoming Casablancan: Fessis in Casablanca as a case study", in C. Miller, E. Al-Wer, D. Caubet, \& J. C. E. Watson (eds.), Arabic in the city: Issues in dialect contact and language variation, London: Routledge, 97-122.

HAZEN, K. (2002) "Identity and language variation in a rural community", Language, 78 (2), 240257.

JABouR, J. (2010) Oyoun Z-Zajal wa Oyoun Al-Wadi 'The Springs of Z-Zajal (i.e. type of competitive poetry sang in a special way stretching the words at the end, shaking the tabor before the start of each turn and at the end of each turn) and the Springs of the Valley', Oyoun Al-Wadi, Hims, Syria.

JøRGENSEN, J. N. (2003) "Linguistic Construction and Negotiation of Social Relations among Bilingual Turkish-speaking Adolescents in North-western Europe", Journal of Multilingual and Multicultural Development, 24 (1), 1-11.

KERSWILL, P. (1993) "Rural dialect speakers in an urban speech community: the role of dialect contact in defining a sociolinguistic concept", International Journal of Applied Linguistics, $3(1), 33-56$.

KERSWILL, P. (1996) “Children, adolescent, and language change", Language Variation and Change, 8, 177-202.

KeRSWILL, P. \& A. Williams. (2000) “Creating a New Town koine: Children and language change in Melton Keynes", Language in Society, 29, 65-115.

LABOV, W. (2010) Principles of linguistic change: Vol. 3. Cognitive and cultural factors. Malden, MA: Wiley-Blackwell.

MA'LOUF, H. E. (1978) Qariati Oyoun Al-Wadi/Mon Village Ouyoun El-Wadi 'My Village Oyoun AlWadi', Latakia, Syria: Matba'at Al-Balagha.

MILLER, C. (2005) "Between accommodation and resistance: Upper Egyptian migrants in Cairo", Linguistics, 43 (5), 903-956.

NeSdale, D. \& R. Rooney (1996) "Evaluations and Stereotyping of Accented Speakers by PreAdolescent Children", Journal of Language and Social Psychology, 15, 133-154.

ORNAGHI, D. (2010) "A phonological study of the spatial diffusion of urban linguistic forms to the varieties of the Nile Delta", Journal of Sociolinguistics, 14 (2), 184-206. 
PAYNE, A. C. (1980) "Factors controlling the acquisition of the Philadelphia dialect by out-of-state children", in W. Labov (ed.), Locating language in time and space, New York: Academic Press, 143-178.

RoBertS, J. (2004) “Child language variation”, in J. K. Chambers, P. Trudgill, \& N. Schilling-Estes (Eds.), The handbook of language variation and change, Malden, MA: Blackwell, 333-348.

ROMAINE, S. (1995) Bilingualism, Oxford: Blackwell.

Tagliamonte, S. A. \& S. Molfenter (2007) "How'd you get that accent?: Acquiring a second dialect of the same language", Language in Society, 36, 649-675.

StANFORD, J. N. (2008) "Child dialect acquisition: New perspectives on parent/peer influence", Journal of Sociolinguistics, 12 (5), 567-596.

TURELL, M. T. (2003) "Apparent and real time in studies of linguistic change and variation", Noves SL. Revista de Sociolingüística, 1-10. [http://www.gencat.cat/llengua/noves]

WALTERS, K. (1989) Social change and linguistic variation in Korba, a small Tunisian town, Unpublished doctoral dissertation, University of Texas, Austin.

WALTERS, K. (1991) "Women, men, and linguistic variation in the Arab World", in B. Comrie, \& M. Eid (eds.), Perspectives on Arabic Linguistics III, Amsterdam: John Benjamins, 199-229.

WALTERS, K. (1992) "A sociolinguistic description of (u:) in Korba Arabic: Defining linguistic variables in contact situations and relic areas", in E. Broselow, M. Eid, \& J. McCarthy (eds.), Perspectives on Arabic linguistics IV [Current Issues in Linguistic Theory 85], Amsterdam: John Benjamins, 181-217. 